\title{
Problem wielokulturowości i kryzysu migracyjnego we współczesnym kinie europejskim
}

\begin{abstract}
Streszczenie
Celem rozważań zawartych w artykule jest próba znalezienia odpowiedzi na pytanie, czy i jak filmy poruszające problematykę wielokulturowości mogą służyć edukacji i komunikacji międzykulturowej, wychowaniu ku tolerancji, zapobieganiu rasizmowi, uprzedzeniom i negatywnym stereotypom? Współczesne kino coraz częściej konfrontuje widza z ideą wielokulturowości oraz skłania do namysłu nad wzajemną akceptacją i tolerancją kulturowego zróżnicowania. Ukazywanie mniejszości etnicznych i rasowych w filmach łączy się z refleksją nad ruchami migracyjnymi oraz problemami wielokulturowych społeczeństw. Zgodnie z przyjętym założeniem filmy o tej tematyce mogą wspomagać proces komunikacji i edukacji międzykulturowej.
\end{abstract}

\section{Słowa kluczowe:}

film, wielokulturowość, migracje, edukacja międzykulturowa

\section{Abstract}

The purpose of the reflections in the article is an attempt to find an answer to the question of whether and how films speaking about the topic of multiculturalism could serve intercultural education and communication,

1 Ewelina Konieczna, Wydział Nauk Społecznych, Uniwersytet Śląski w Katowicach, Polska, e-mail: ewelina.konieczna@us.edu.pl, ORCID ID: https://orcid.org/0000-0002-8042-3956. 
upbringing towards tolerance, preventing racism, prejudice, and negative stereotypes. More and more often, modern cinema audience experiences multiculturalism and is encouraged to reflection about mutual acceptance and tolerance of cultural diversity. Presenting in films ethnical and racial minorities is connected with reflection on migratory movements and the issues of multicultural societies. According to the adopted assumption, films on this subject can support the process of communication and intercultural education.

\section{Keywords:}

film, multiculturalism, migration, intercultural education

\section{WPROWADZENIE}

Współczesny film jest tekstem kultury ściśle powiązanym z aktualną sytuacją polityczną i społeczną. Kino porusza ważne problemy społeczne, dotyczące między innymi nierówności, biedy czy różnych rodzajów wykluczenia. Bohaterami filmów coraz częściej są przedstawiciele mniejszości etnicznych, imigranci i uchodźcy. „Twórcy filmowi chętnie podejmują temat tożsamości etnicznej, analizują sytuację grup mniejszościowych, a co za tym idzie problem stosunków władzy i hegemonii kulturowej” (Loska, 2016, s. 26). Krzysztof Loska (2016) autor opracowania Postkolonialna Europa. Etnoobrazy współczesnego kina, wpisującego się w nurt postkolonialnych studiów nad filmem, powołując się na innych badaczy tego zagadnienia między innymi Ellę Shohat i Roberta Stama (1994), podkreśla że postkolonializm w dzisiejszym rozumieniu to nie jest czas po kolonializmie i początek nowej epoki, ale proces wskazujący na powiązanie przeszłości i teraźniejszości oraz „diasporyczną obecność dawnych podporządkowanych Innych w metropolitarnym centrum” (Loska, 2016, s. 24). Ukazywanie mniejszości etnicznych i rasowych w filmach łączy się dziś nieuchronnie z refleksją nad ruchami migracyjnymi, problemami wielokulturowych społeczeństw i coraz częściej z doskwierającym Europie nierozwiązanym „kryzysem migracyjnym”, czyli używając słów Zygmunta Baumana (2016) - „kłopotliwymi”, ,irytującymi”, „,niechcianymi”, „niedopuszczalnymi” uchodźcami. Bauman przekonuje, że problemy związane z obecnością „innych pośród nas” są uniwersalne i ponadczasowe: „Uchodźcy uciekający przed bestialstwem wojny i despotyzmem lub barbarzyństwem, na jakie skazuje życie w głodzie i bez perspektyw, od zarania nowoczesności pukali do cudzych drzwi. Z punktu widzenia tych, którzy stoją po drugiej stronie, ci przybysze byli zawsze 
- tak jak i teraz - obcymi. Budzą niepokój właśnie z powodu swojej »obcości«, która ma sprawiać, że są przerażająco nieprzewidywalni, w odróżnieniu od ludzi, z którymi zadajemy się na co dzień i po których, jak nam się wydaje, wiemy, czego się spodziewać. Z tego, co wiemy, ogromny napływ obcych może przecież unicestwić to, co sobie ceniliśmy, zaburzyć lub zniszczyć nasz kojąco swojski styl życia” (Bauman, 2016, s. 14-15).

W ostatnich latach w Europie systematyczne zwiększa się liczba uchodźców, nielegalnych imigrantów i osób starających się o status uchodźcy. Jest to doświadczenie nie tyle nowe, co nieprzewidziana konsekwencja chybionych interwencji zbrojnych w Afganistanie i Iraku, które skutkują nie tylko obaleniem reżimów, ale i nieograniczonym, przynoszącym zyski handlem bronią. Nasilenie ruchów migracyjnych i nieumiejętność systemowego radzenia sobie z tym zjawiskiem stały się przyczyną nieporozumień i konfliktów pomiędzy państwami członkowskimi Unii Europejskiej. Niektóre demokratyczne rządy zmieniły swą politykę imigracyjną, tworząc zamknięte ośrodki dla cudzoziemców czekających na przyznanie im prawa do pobytu tymczasowego czy uchwalając ustawy umożliwiające deportację uchodźców za drobne wykroczenia.

W obliczu tej skomplikowanej sytuacji polityczno-społecznej europejscy filmowcy podejmują próby zmierzenia się z tematem kłopotliwego obcego - migranta i uchodźcy, a problemy dotyczące tożsamości kulturowej i kulturowych różnic stają się pretekstem do refleksji nad lękami i obawami Europejczyków. Warto się zastanowić, czy i w jakim zakresie filmy ukazujące odmienność, różnice kulturowe oraz problemy związane między innymi z migracją, tożsamością kulturową i etniczną mogą stanowić narzędzie służące niwelowaniu lęków przed obcym i jego odmiennością. Jak filmy poruszające problematykę wielokulturowości mogą służyć komunikacji i edukacji międzykulturowej, wychowaniu ku tolerancji, zapobieganiu rasizmowi, uprzedzeniom i negatywnym stereotypom? Próba znalezienia odpowiedzi na powyższe pytania wraz z refleksją nad możliwością wykorzystania filmów w komunikacji i edukacji międzykulturowej stanowi cel zawartych w artykule rozważań.

\section{KRYZYS IDEI WIELOKULTUROWOŚCI I EDUKACJI MIĘDZYKULTUROWEJ}

Społeczeństwa wielokulturowe stały się dzisiaj faktem, jednakże źródła i formy wielokulturowości są zróżnicowane. Z punktu widzenia współczesnej antropologii nie do przyjęcia jest teza o związku odmienności kulturowej z podłożem biologicznym człowieka, jako że łączy się ze szkodliwą ideologią rasistowską. Naturalne 
natomiast jest dostrzeganie i docenienie w praktyce społecznej różnorodności kulturowej w kategorii „swój-obcy”, co wiąże się z wielostopniową konstrukcją układów i relacji społecznych. Każda grupa spotyka się zwykle z więcej niż jedną inną grupą postrzeganą jako obca z różnych względów: językowych, religijnych, etnicznych, narodowych, a „konstrukcje swojskości i obcości mają swoją dynamikę, która okresowo nabiera większego impetu; zmiany całych konstrukcji swojskości i obcości w sytuacjach kryzysów społecznych zyskują na intensywności” (Nowicka, 2010, s. 325). Ewa Nowicka (2010) podkreśla również, że postrzeganie odmienności kulturowej w kategoriach „swojskości” i „obcości” jest, podobnie jak kategorie czasu i przestrzeni, niezbywalnym elementem ludzkiego myślenia, od którego nie sposób się uwolnić. Można jednak próbować uchronić się od zgubnych skutków przeobrażania się kategorii obcości we wrogość (Nowicka, 2010).

Pojęcie wielokulturowości funkcjonuje zarówno na poziomie opisu rzeczywistości społecznej (systemu wartości), jak i ideologii (programu działania podporządkowanemu danemu systemowi wartości). Wielokulturowość związana jest z określonymi sytuacjami, które ją kontekstowo definiują, mianowicie:

„1) z bliskością terytorialną zbiorowości kulturowo odmiennych,

2) ze znaczącym w odczuciu społecznym stopniem kulturowej odmienności zbiorowości pozostających w kontakcie,

3) z jakąś, choćby najsłabszą, formą kontaktów między jednostkami należącymi do zbiorowości kulturowo odmiennych

4) z jakimś stopniem i sposobem izolacji czy separacji tych grup” (Nowicka, 2010, s. 326).

Istnieje wiele sposobów rozumienia i definiowania terminu „wielokulturowość”, który przede wszystkim koncentruje się na wymiarze etniczności związanym z zajmowanym obszarem geograficznym oraz na zetknięciu się ze sobą przedstawicieli przynajmniej dwóch narodowości (Mamzer, 2002). Marian Golka (2010) określa wielokulturowość jako: „uświadomione współwystępowanie na tej samej przestrzeni (albo w sąsiedztwie bez wyraźnego rozgraniczenia, albo w sytuacji aspiracji do zajęcia tej samej przestrzeni) dwóch lub więcej grup społecznych o odmiennych cechach wyróżniających: wyglądzie zewnętrznym, języku, wyznaniu religijnym, systemie wartości itd., które przyczyniają się do wzajemnego postrzegania odmienności z różnymi skutkami” (Golka, 2010, s. 64-65).

Jednym z czynników prowadzących do kulturowej różnorodności i wielokulturowości są migracje, czyli terytorialne przenoszenie się odmiennych kulturowo grup, prowadzące do bezpośrednich lub pośrednich kontaktów jednostek i grup o innym kulturowym zapleczu oraz wychowanych w innych systemach wartości, pojęć i wzorów zachowania. Migrantami są polityczni uchodźcy, osoby, które sta- 
rają się o uzyskanie statusu uchodźcy, studenci, pracownicy kontraktowi czasowo przebywający w danym kraju czy osoby mieszkające na stałe w innym, niż własny ze względów ekonomicznych bądź rodzinnych (np. małżeńskich), co tworzy nowe typy wielokulturowości na płaszczyźnie rodzinnej (Nowicka, 2010).

„Wszyscy terroryści są migrantami” - te znamienne słowa wypowiedziane w 2015 roku przez premiera Węgier Viktora Orbana w okresie znaczącego napływu uchodźców z objętej wojną Syrii położyły się cieniem na współczesną Europę, która czuje się coraz bardziej zagrożona. Jedną z konsekwencji lęku przed odmiennością kulturową i religijną migrantów jest ich stygmatyzacja, odmowa akceptacji społecznej i alienacja, co przyczynia się do „radykalizacji młodych muzułmanów” - pisze Zbigniew Bauman (2016), powołując się na słowa Pierra Baussanda z organizacji Social Platform.

Refleksja nad edukacją międzykulturową, czy może bardziej nad przyczynami jej kryzysu, staje się jednym z ważniejszych zagadnień współczesnej polityki edukacyjnej państw europejskich. Badania prowadzone w krajach europejskich (np. Wielkiej Brytanii, Danii, Szwecji, Belgii, Austrii, Szwajcarii, czy we Włoszech) wskazują na niechęć do idei społeczeństwa wielokulturowego i aktualnej polityki migracyjnej, zwłaszcza wśród ugrupowań populistycznych i skrajnie prawicowych. Wyniki tych badań (prowadzonych jeszcze przed rozpoczęciem wojny w Syrii w 2011 roku, która spowodowała nasilenie ruchów migracyjnych) wskazują na kryzys tej edukacji, sprzyjający tworzeniu się atmosfery postmultikulturowej oraz postrzeganiu idei społeczeństwa wielokulturowego jako mitu politycznego i edukacyjnego. Komisja Europejska już w 1984 roku wydała Raport dla Rady Europy, w którym wyznaczyła cele wychowania w oparciu o społeczną inkluzję, przełamywanie izolacji społecznej i marginalizacji oraz umacnianie dialogu kultur. Sukcesywnie w rozmaitych dokumentach formułujących założenia europejskiej polityki edukacyjnej pojawiają się zapisy zachęcające do włączenia edukacji międzykulturowej do programów szkolnych, pozaszkolnych, jak również do programu kształcenia nauczycieli. W wielu krajach europejskich dzieci imigrantów są objęte programem edukacyjnym służącym integracji kulturowej oraz zachowaniu tożsamości kulturowej: To jednak ciągle nie wystarcza, współczesna edukacja międzykulturowa nie może ograniczać się do murów szkolnych i młodego pokolenia, musi zostać wpisana w nurt działań społecznych i kulturowych opartych na budowaniu wiedzy o różnorodności kulturowej i szacunku dla wszystkich ludzi, działań zarówno formalnych, jak i nieformalnych skierowanych do różnych grup wiekowych (Dąbrowa, 2010).

Termin edukacja międzykulturowa, który zastąpił wcześniejsze pojęcie edukacji wielokulturowej, (które w mniejszym stopniu eksponowało interakcyjność 
działań) Jerzy Nikitorowicz (2009) rozumie jako: „ogół wzajemnych wpływów i oddziaływań jednostek i grup, instytucji, organizacji, stowarzyszeń, związków sprzyjających takiemu rozwojowi człowieka, aby stawał się on w pełni świadomym i twórczym członkiem wspólnoty rodzinnej, lokalnej, regionalnej, wyznaniowej, narodowej, kontynentalnej, kulturowej i globalnej/planetarnej oraz był zdolny do aktywnej samorealizacji, kształtowania trwałej tożsamości i odrębności. Skutkiem edukacji ma więc być dynamizacja społeczno-kulturowa różnych grup, wzajemne poznanie, zbliżenie i integracja, z zachowaniem własnej odrębności i własnych wizji rozwoju. Stąd podstawową zasadą jest nieredukowalna różnica, dotycząca zarówno grup mniejszościowych, jak i grupy większościowej. Różnicę traktuje się bowiem nie tylko jako wartość samą w sobie, a także jako cechę konstytutywną człowieka oraz czynnik wzajemnego rozwoju” (Nikitorowicz, 2009, s. 282). Przestrzenią współczesnej nieformalnej edukacji międzykulturowej może być kino, które od początku istnienia było wykorzystywane w dialogu na temat ważnych społecznych problemów - czy i na ile skutecznie, to już inna sprawa.

\section{MIGRANCI WE WSPÓŁCZESNYM KINIE EUROPEJSKIM}

W 2012 roku na ekranach kin można było zobaczyć komedię pt. Nietykalni (Intouchables) wyreżyserowaną przez Oliviera Nakache, Francuza algierskiego pochodzenia, i Érica Toledano, którego rodzice pochodzą z Maroka. Dwa lata później - w 2014 roku widzowie w całej Europie chętnie oglądali inną francuska komedię Za jakie grzechy, dobry Boże (Qu'est-ce-qu'on a fait Au Bon Dieu) w reżyserii Philippe de Chauveron. Filmy te to typowe blockbustery (w samej Francji każdy z nich obejrzało kilkanaście milionów widzów), które nie tylko bawią, ale zabierają głos na temat pozytywnie postrzeganej imigracji, stanowiącej czynnik społecznego postępu i konsekwencję francuskiej historii. Nie ma w nich mowy o zagrożeniu dla bezpieczeństwa, pracy czy tożsamości kulturowej rdzennych Francuzów, czyli stanowiska wykorzystywanego przez prawicowe frakcje polityczne. Mają one jednak wyraźne ideologiczne nacechowanie. Bohaterów Nietykalnych - sparaliżowanego arystokratę i jego młodego opiekuna pochodzącego z nizin społecznych, tryskającego energią imigranta łączy przyjaźń i specyficzna emocjonalna więź, mimo wszelkich możliwych różnic pomiędzy nimi: społecznych, ekonomicznych, intelektualnych i fizycznych. Jest to film z wyraźną tezą zakładającą, że obaj są sobie tak samo potrzebni, co stanowi natrętną dydaktykę mówiącą o wzajemnej, koniecznej zależności francuskiego zróżnicowanego etnicznie i kulturowo społeczeństwa. Idea tak wyobrażonej jedności przybiera formę propagandy, którą 
kupują widzowie, zasypiając ze spokojnym sumieniem i poczuciem, że wszystko jest w najlepszym porządku - obcy został oswojony i zasymilowany.

Tytułowe pytanie Za jakie grzechy, dobry Boże? zadają sobie przerażeni rodzice, kiedy dowiadują się, że ich cztery córki wybrały sobie mężów z innych kręgów kulturowych - o pochodzeniu arabskim, żydowskim, chińskiego imigranta i katolika z Afryki. Początkowo krzywdzące stereotypy wiążące się z wyobrażonymi cechami przyszłych zięciów zaślepiają zatroskanych o los córek rodziców, by po wspólnie spędzonym czasie Bożego Narodzenia „lody pękły” i zagościło wzajemne zrozumienie, tolerancja oraz równość i braterstwo deklarowane w podczas wspólnego odśpiewania Marsylianki. Paradoksalnie osobą o wyraźnych uprzedzeniach kulturowych i rasowych okazuje się nie francuski ojciec, ale afrykański teść jednej z córek, przeciwny mieszanym małżeństwom. Reżyser i scenarzysta Philippe de Chauveron oparł filmową opowieść na autobiograficznym wątku, bowiem zarówno on, jak i jego brat poślubili kobiety o nieeuropejskim pochodzeniu etnicznym. Osobiste doświadczenie przeniesione do filmowej opowieści posłużyło do zbudowania określonej strategii autorskiej projektującej odbiór filmu, modelującej poglądy i opinie widzów na temat mieszanych małżeństw, kulturowej odmienności i obcości, która w efekcie wszystkich wzbogaca, zamiast dzielić. Tezą (morałem?) filmu jest powszechna prawda mówiąca, że nie lubimy i boimy się tego, czego nie znamy. Oswojony lęk przestaje być groźny, a negatywne emocje na drodze wzajemnego zrozumienia i tolerancji mogą przerodzić się w pozytywny stosunek do wszelkiej inności. W 2019 roku na ekrany wszedł film będący kontynuacją Za jakie grzechy, dobry Boże? Tym razem w opowieści zatytułowanej I znowu zgrzeszyliśmy, dobry Boże (Qu `est-ce qu `on a encore fait au bon Dieu?) Philippe de Chauveron ukazuje Francję, również tę prowincjonalną, jako przyjazny i gościnny kraj, dający migrantom szansę na znalezienie miłości i osobisty rozwój.

Popularne i oparte na baśniowej strukturze komedie, które opowiadają o bohaterach dzielnie pokonujących piętrzące się trudności, by w finale odnaleźć swą tożsamość i bezwarunkowo pokochać nowy kraj, są, wydaje się, francuską specialite de la maison. Kolejna komedia z 2016 roku (dostępna na platformie Netflix), to Afrykański doktor (Bienvenue à Marly-Gomont, reż. Julien Rambaldi). Opowieść, została osadzona w latach 70. XX wieku, a jej scenariusz napisano na podstawie prawdziwej historii wykształconego we Francji kongijskiego lekarza, który nie chcąc wracać do kraju rządzonego przez dyktatora Mobutu, zachęcony obietnicą uzyskania francuskiego obywatelstwa, zdecydował się sprowadzić rodzinę i podjąć pracę na prowincji. Jak można się spodziewać, początki nie były łatwe nie tylko dla lekarza, któremu bardzo trudno jest zdobyć zaufanie pacjentów, ale i dla dzieci obrażanych i prześladowanych przez rówieśników, jak również dla 
tęskniącej za rodziną żony. Film w zabawny sposób ukazuje zmaganie się afrykańskiej rodziny z brakiem tolerancji sąsiadów, głupotą i złośliwością urzędników. Ale jak to w baśniach bywa, wszystko dobrze się kończy, bo małomiasteczkowa społeczność w końcu docenia zaangażowanie doktora i jego żony, a dzieci zostają zaakceptowane w szkole i znajdują przyjaciół. Rodzina z Konga w pełni się zasymilowała i przyjęła lokalne zwyczaje, stając się częścią społeczności. Mamy tutaj do czynienia z idealnym modelem imigranta znaturalizowanego zgodnie z oczekiwaniami europejskiego postkolonialnego świata.

Można mieć wątpliwości, czy komediowa konwencja jest adekwatna do wagi problemu oraz czy i w jakim zakresie wyidealizowany wizerunek „dobrego”, zasymilowanego imigranta może zmienić lub ukształtować na nowo opinie, poglądy i postawy wobec niego. Czy taka forma ideologicznie nacechowanej dydaktyki trafia do tych, którzy szczególnie potrzebują międzykulturowej edukacji ze względu na wrogi czy niechętny stosunek do „obcego u swoich drzwi”? Omówione filmy na pewno w jakimś stopniu ocieplają wyobrażenie o imigrantach, może budzą refleksję na temat potencjalnego sąsiada - takiego samego Innego - o obcym etnicznym pochodzeniu, co stanowi pierwszy krok ku tolerancji i akceptacji odmienności. Zachodzi jednak obawa, że konwencja zabawnej komedii trywializuje i bagatelizuje problem. Ponadto można mieć wątpliwości, czy niewymagający widzowie, gustujący przede wszystkim w łatwych w odbiorze komediach, są zainteresowani jakimkolwiek głębszym namysłem nad uwarunkowaniami sytuacji społecznej, kulturowej i politycznej imigrantów, czy filmowe perypetie bohaterów będą odbierać wyłącznie na poziomie czerpania przyjemności z sytuacyjnych żartów. Choć skądinąd śmiech, rozładowujący napięcie emocjonalne, ma moc oczyszczającą, pomaga również uporać się z lękiem, redukując poziom hormonów stresu (m.in. kortyzolu), więc może komedie są jednak przydatne w komunikacji międzykulturowej?

Filmowe dramaty dotyczące problemu wielokulturowości nie trafiają niestety do szerokiej widowni tak łatwo jak komedie, które funkcjonują w obiegu festiwalowym i arthouse’owym. Przykładem takiego kina jest twórczość niemieckiego reżysera, potomka tureckich emigrantów, urodzonego w Hamburgu Fatiha Akina. Od pierwszych krótkometrażowych filmów realizowanych pod koniec lat 90. XX wieku po najnowszy film z 2017 roku pt. W ułamku sekundy (Aus dem Nichts) twórca porusza problem tureckiej diaspory, stereotypów etnicznych i wieloetnicznego społeczeństwa współczesnej Europy. Akin w jednym ze swoich pierwszych ważnych filmów Głowq w mur (Gegen die Wand, 2004) opowiada o poszukiwaniu własnego miejsca w wielokulturowym świecie i pokazuje, że proces integracji wiąże się zazwyczaj z kryzysem tożsamości, jest niezwykle trudny i bolesny, a relacje między kulturami większości i mniejszości sprzyjają napięciom (Loska, 2016). 
W ułamku sekundy, poruszająca historia małżeństwa Katji i Nuriego - Niemki i Turka z kryminalną przeszłością, zaczyna się relacją wideo ze ślubu w więzieniu. Po latach udanego i szczęśliwego związku dochodzi do tragedii w biurze Nuriego, gdzie w czasie bombowego zamachu mężczyzna ginie wraz z sześcioletnim synem. Jednakże zarówno w czasie śledztwa, jak i procesu sądowego oskarżonych o zamach niemieckich neonazistów, jako bezpośrednie przyczyny tragedii wskazywane są etniczne pochodzenie i kryminalna przeszłość Nuriego. Do głosu dochodzą tutaj wszystkie możliwe stereotypy i uprzedzenia w myśl niefortunnego powiedzenia Viktora Orbana „wszyscy terroryści są migrantami”, a sprawcy zamachu (para młodych Niemców) zostają uniewinnieni. Ta emocjonalna opowieść, wykorzystując jednostkowe losy bohaterów, pokazuje zmagania z nietolerancją i nacjonalistyczną nienawiścią. W rozpaczliwej walce o sprawiedliwość pogrążona w bezgranicznej rozpaczy Katja nie godzi się ze stygmatyzacją męża, szukając pocieszenia w zemście. Wstrząsający film o zderzeniu kultur oraz konfrontacji niespójnych i przeciwstawnych wartości jest kolejnym apelem reżysera na rzecz prawa do różnorodności.

Kino eksplorujące tematykę migracyjną powstaje w krajach, które dotknął migracyjny kryzys. Nie tylko twórcy z Francji i Niemiec, ale również Szwedzi czy Finowie stworzyli w ostatnich latach filmy pochylające się nad losem migrantów. W refleksję na temat kondycji sytego, zachodniego świata nieuchronnie wplatane są wątki wywołujące dyskomfort widza - zadowolonego i pewnego siebie obywatela Zachodu. Szwedzki film The Square (reż. Ruben Östlund, 2017) to przede wszystkim satyra na współczesną sztukę i krytyka społecznej znieczulicy, ale również opowieść o lęku o własny, bezpieczny świat i strachu przed Innym, tłumionym przez poprawność polityczną. Östlund eksponuje fałszywą tolerancję szwedzkiego społeczeństwa wobec różnorodności i wyraża niezgodę na taki stan rzeczy, co ukazuje w scenie z chłopcem o obcym pochodzeniu etnicznym, zabierającym pełen oburzenia głos w sprawie niesłusznego oskarżenia o kradzież. Choć oskarżenie, a raczej listowne polecenie oddania skradzionych przedmiotów, nie było skierowane wyłącznie do rodziny chłopca, ale do stu pięćdziesięciu innych rodzin mieszkających w jednym z budynków usytuowanych w biednej dzielnicy, gdzie poszkodowany zlokalizował swój skradziony telefon. Szczery sprzeciw chłopca wobec posądzenia jego rodziny o kradzież portfela, telefonu i spinek do mankietów budzi przerażenie okradzionego dyrektora muzeum sztuki nowoczesnej przed konsekwencjami gniewu potomków imigrantów, urodzonych i wychowanych w zachodnim świecie. Znamienne, że spośród wszystkich lokatorów tylko mały chłopiec stanął w obronie honoru rodziny. Inni już się przyzwyczaili? $\mathrm{W}$ The Square utożsamianie problemu migracji z problemem jednostkowego 
i narodowego bezpieczeństwa prowadzi do stygmatyzacji obcych. Za publicznym przyzwoleniem migranci są pierwszymi podejrzanymi w sprawie nawet drobnego wykroczenia - i domagają się sprawiedliwości.

Problem „kryzysu migracyjnego” pojawia się w filmach fińskiego twórcy Aki Kaurismäkiego pt. Człowiek z Hawru (Le Havre, 2011) oraz Po tamtej stronie (Toivon tuolla puolen, 2017). W głęboko humanistycznych fabułach o baśniowej strukturze reżyser bezpośrednio nawiązuje do problemu migracji, oskarżając Europę o brak solidarności z uchodźcami. Człowiek z Hawru opowiada historię nielegalnego imigranta - chłopca z Gabonu, któremu bezrobotny rybak daje schronienie przed szukającą go policją. Kaurismäki krytykuje w filmie politykę imigracyjną, służącą głównie ograniczeniu napływu uchodźców i wzmocnieniu granic. Apeluje o zwyczajną ludzką przyzwoitość, która wymaga od nas, aby pomagać słabszym i tym, którzy tej pomocy bezwzględnie potrzebują. Reżyser przypomina o idei gościnności w duchu myśli Jacquesa Derridy, której utopię konstruuje w swoim filmie. Gościnności, o której - jak zauważa Krzysztof Loska - europejskie społeczeństwo zapomniało. „Utopijna wymowa Człowieka z Hawru wynika poniekąd z powrotu do gościnności bezwarunkowej, w której gospodarz nie oczekuje od gościa wdzięczności, nie domaga się od niego dokumentów potwierdzających tożsamość, ale udziela pomocy i schronienia bezinteresownie, nie licząc na wzajemności i płynące z niej korzyści. Gościnność posiada tu przede wszystkim wymiar etyczny, wiąże się z otwarciem na Innego, opiera się na idei solidarności i odpowiedzialności za drugiego człowieka” (Loska, 2016, s. 160).

Bohaterem Po tamtej stronie jest Syryjczyk, który poszukuje w Europie swej zagubionej w czasie ucieczki z Aleppo siostry. Ciężar gatunkowy filmu sytuuje się pomiędzy komediowymi filmami o bezbolesnej asymilacji migrantów a dramatami krytykującymi bierność europejskiego społeczeństwa w stosunku do imigrantów. Kaurismäki z charakterystyczną dla swej twórczości lekkością i gorzkim humorem przedstawia działania personelu restauracji, który solidarnie wspiera uchodźcę. Szczera empatia i determinacja szefa oraz pracowników restauracji, w której Syryjczyk znalazł nie tylko zatrudnienie, ale i przyjaciół, prowadzą do ukazania jednego z możliwych wariantów działań pomocowych i zapewnienia poczucia wspólnoty, mimo dzielących ludzi różnic. Świat przedstawiony w opowieści przypomina nieco baśniowe francuskie komedie o „dobrych imigrantach”, jednak brak mu propagandowego i populistycznego zadęcia. Relacja pomiędzy rozczarowanym życiem fińskim restauratorem a młodym uchodźcą, podobnie jak ta ukazana w Nietykalnych, stanowi metaforę stosunku Europy do imigrantów, jednak wydaje się bardziej realna i uczciwa. Ewolucja nastawienia bohaterów - 
od wrogości, przez wzajemne zrozumienie, do poczucia solidarności w obliczu życiowego kryzysu - stanowi o wiarygodności intencji reżysera.

\section{ZAKOŃCZENIE}

Kino może wspomagać proces komunikacji i edukacji międzykulturowej jako forma dialogu kultur. Przynajmniej ma taką potencjalną siłę. Obecność w przestrzeni społecznej filmów poruszających zagadnienia wielokulturowości ma szansę pobudzić do refleksji nad uprzedzeniami, wrogością i lękiem wobec obcych. Można założyć, że współczesne kino o takiej tematyce służy także podtrzymywaniu tożsamości poszczególnych społeczności i osób, promowaniu tolerancji, otwartości na Inność. Natomiast twórcze uwydatnianie kulturowego zróżnicowania przez świadomych artystów, propagowanie sensu uniwersalnych wartości oraz sprawiedliwości społecznej bez względu na płeć, rasę, wyznanie, pochodzenie etniczne i społeczne nie będzie tylko kolejnym działaniem na rzecz fałszywej tolerancji, lecz przyczyni się do brzemiennego w skutkach namysłu nad kondycją naszego zróżnicowanego kulturowo świata. Ważne społecznie filmy pomagają w uświadamianiu obecności różnych kultur w społeczeństwie, przyczyniają się do traktowania ich jako czynnika wzajemnego wzbogacania, obrazują różne formy konfrontacji często niespójnych i przeciwstawnych wartości, ukazują możliwości mediacji i drogi rozwiązywania konfliktów.

Przywołane tytuły stanowią skromną egzemplifikację współczesnych filmowych fabuł, które ilustrują problemy wielokulturowości, migracji i uchodźców, a podjęte w artykule rozważania nie wyczerpują złożoności problematyki. Co roku na ekrany kin oraz do obiegu medialnego wchodzą kolejne filmy rozpatrujące zarówno dawne, jak i nowe problemy związane z wielo- i międzykulturowością, które są odbiciem narastających w Europie i poza nią konfliktów politycznych. Trwale obecne w światowej kinematografii motywy Innego i obcego są rozmaicie analizowane i interpretowane. Dzisiaj kino sugeruje, że współczesna Europa wymaga terapii szokowej podobnej do tej, jakiej w filmie The Square zostali poddani goście biorący udział w bankiecie, podczas którego „człowiek-małpa” zamienia bezpieczną salę bankietową w dżunglę, a wspólna przestrzeń porozumienia okazuje się utopią. Czy zatem, jak zakłada Ruben Östlund reżyser The Square, wzajemne (po)rozumienie ponad kulturowymi różnicami rzeczywiście nie jest możliwe? Drogę do porozumienia i pokojowego, solidarnego współistnienia coraz częściej dostrzega się w rozmowie, więc mimo wszystko można mieć nadzieję, że współczesne kino odegra istotną rolę w międzykulturowym dialogu. 


\section{Bibliografia}

Bauman, Z. (2016). Obcy u naszych drzwi. Warszawa: PWN.

Dąbrowa, E. (2010). Kryzys edukacji międzykulturowej w społeczeństwach zróżnicowanych kulturowo (na przykładzie wybranych krajów). W: D. Pietrzyk-Reeves, M. Kułakowska (red.), Studia nad wielokulturowościq (s. 199-212). Kraków: Księgarnia Akademicka, Uniwersytet Jagielloński.

Golka, M. (2010). Imiona wielokulturowości. Warszawa: Warszawskie Wydawnictwo Literackie Muza SA.

Mamzer, H. (2002). Tożsamość w podróży. Wielokulturowość a kształtowanie tożsamości jednostki. Poznań: Wydawnictwo Naukowe, Uniwersytet im. Adama Mickiewicza.

Nikitorowicz, J. (2009). Edukacja regionalna i międzykulturowa. Warszawa: Wydawnictwa Akademickie i Profesjonalne.

Nowicka, E. (2010). Czy możliwe jest społeczeństwo wielokulturowe? Doświadczenia antropologa. W: D. Pietrzyk-Revees, M. Kułakowska, (red.), Studia nad wielokulturowościq. (s. 323-352). Kraków: Księgarnia Akademicka, Uniwersytet Jagielloński.

Loska, K. (2016). Postkolonialna Europa. Etnoobrazy współczesnego kina. Kraków: Universitas.

Shoahat, E., Stam, R. (1994). Unthinking Eurocentrism: Multiculturalism and the Media. New York: Routledge. 